\title{
Real Exchange Rate Adjustment In European Transition Countries*
}

\author{
Florin G. Maican ${ }^{\dagger}$ \\ Department of Economics, School of Economics and Commercial Law, \\ Göteborg University \\ Richard J. Sweeney ${ }^{\ddagger}$ \\ McDonough School of Business, \\ Georgetown University
}

First draft: April 2003

Last revised: December 2005

\begin{abstract}
This paper presents unit-root test results for real exchange rates in ten Central and Eastern European transition countries during 1993:01-2003:12. Because of the shift from controlled to market economies and the accompanying crises, failed policy regimes and changes in exchange rate regimes, appropriate tests in transition countries require allowing for both structural changes and outliers. In both single-equation tests and panel tests with SUR techniques, the data reject the unit-root null for the CEE countries. Accounting for structural breaks and outliers gives much faster mean-reversion speeds than otherwise.

Keywords: Purchasing power parity; real exchange rate; Monte Carlo; unit root; transition countries; panel data.

JEL Classification: C15, C22, C32, C33, E31, F31.
\end{abstract}

\footnotetext{
${ }^{*}$ Thanks are due to Erik Hjalmarsson, Lennart Hjalmarsson, Sorin Maruster, Eugene Nivorozhkin, Bernhard Pfaff, Violeta Piculescu, Jesper Rangvid, Cătălin Stărică, Rick Wicks and Finn Østrup, and to participants at a seminar in the Finance Institute at the Copenhagen Business School.

${ }^{\dagger}$ Box 640 SE 405 30, Göteborg, Sweden, Phone +46-31-7734759, Fax: +46-31-7734154, E-mail: florin.maican@handels.gu.se

${ }^{\ddagger} 37$ th and "O" Sts., NW, Washington, DC 20057. Phone: 1-202-687-3742. Fax: 1-202-687-4031. E-mail: sweeneyr@georgetown.edu
} 


\section{Introduction}

Purchasing power parity (PPP) is one of the oldest, most studied topics in international finance. Many models of exchange-rate determination are built on the assumption that PPP holds at least in the long run. Much work has been done to test for PPP in developed countries, and more recently a number of papers have tested for PPP in developing countries. Little work, however, has been done on PPP in the transition countries of Central and Eastern Europe (CEE), which are moving from communist planning to free market economies. Of the ten CEE economies discussed here, eight joined the European Union in May, 2004 (the Czech Republic, Estonia, Hungary, Latvia, Lithuania, Poland and Slovakia), and the other two hope to join in 2007 or soon thereafter (Bulgaria and Romania). This paper investigates whether long run PPP holds for these ten CEE transition countries, by testing the unit-root hypothesis for their real exchange rates for the sample period 1993:01-2003:12. Many observers argue that stable long-run real exchange rates are important for real convergence of CEE economies to the rest of the EU and thus for successful integration.

Beyond the intrinsic interest of the CEE economies, the unit-root tests reported below are of methodological interest because the important shifts in the underlying economic processes in these economies require careful test-equation specification. All of these CEE countries switched from controlled to market economies, with the transition more or less prolonged and often subject to major lurches and slow downs. Further, many of these transition countries experienced financial or political crises, abandoned economic-policy regimes that appeared to be failing and adopted other regimes. (Fischer and Sahay (2000) perceptively discuss of twenty-five transition economies' problems, including the ten countries considered here). In particular, transition countries often relied heavily on exchange rates as a stabilization tool, using a range of exchange-rate regimes from managed floats to currency boards, and the majority of CEE countries changed exchange-rate regimes at least once in response to economic difficulties (Table 1). As an example, because of hyperinflation Bulgaria switched in July, 1997, to a currency board against the Deutsche mark. As expected, these exchange-rate-regime changes affected transition-country real exchange rates, often substantially. Furthermore, several transition countries experienced periods of strong real appreciation, which their policy makers attributed to capital-account liberalization, catch-up price rises as non-tradable goods were gradually decontrolled, fiscal imbalances and productivity gains. These turbulent histories appear as structural shifts in real exchange rates in Figure 1 for a number of countries (Bulgaria, Estonia, Latvia and Lithuania, for example) and as outliers (for example, Bulgaria, Romania and perhaps Slovakia).

Tests in this paper allow for structural shifts and outliers. On the other hand, results below strongly support the view that CEE transition economies' real exchange rates show reversion to long-run equilibrium levels; the data show mean reversion whether the U.S. dollar or the Euro is used as the base currency. On the other hand, the results show that failure to allow for parameter 
shifts or for outliers causes bias in test results against mean reversion for the CEE transition economies. Further, the results emphasize that even if test with miss-specified equations correctly reject the unit-root null, failure to take adequate account of parameter shifts and of the outliers can lead to severe under-estimates of real-exchange-rate adjustment speeds.

These results are quite different from those in the few previous unit-root tests of transition economies' real exchange rates. For Hungary and Poland's real exchange rates, in standard singleequation augmented Dickey-Fuller (ADF) tests Dibooglu and Kutan (2001) cannot reject the unitroot null - in contrast to tests below, however, their models allow for neither structural shifts nor outliers. Kim and Korhonen (2002) present panel unit-root tests (based on Hadri (2000)) for real exchange rates in Czech Republic, Hungary, Poland, Slovakia and Slovenia, and reject the null stationarity; their specifications, however, take no account of possible structural shifts or of outliers. Other discussions of real-exchange-rate movements in transition economies do not investigate whether PPP holds, but focus on demand or supply factors (De Broeck and Sløk (2001), Coricelli and Jazbec (2001), and Kim and Korhonen (2002)). Égert (2004) gives a comprehensive review of work on transition economies' real exchange rates. (Kočenda (2005) studies breaks in nominal exchange-rate trends for transition countries.)

Perron (1989) and later papers show that failure to account for structural shifts in time series - for changes in mean or in time trend - biases tests against rejection of the unit-root hypothesis. Related, Franses and Haldrup (1994) and Perron and Rodríguez (2003) show failure to account for outliers biases tests against rejection of the unit-root null. Beyond these size and power issues, this paper addresses the fact that the specification must be appropriate to the data to reduce bias in key parameter estimates - in this paper, the real exchange rate's speed of adjustment.

For ten CEE transition countries, this paper presents the first real-exchange-rate unit-root tests that allow for shifts in means and time trends as well as for outliers, using three sets of models. The first set is based on models proposed by Perron (1989) and generalized by Zivot and Andrews (1992) to allow for possible endogenous shifts in means and time trends. As noted above, because of changes in exchange-rate regimes, financial or political crises, and the large structural changes they have had to make, some transition-country time series appear to show such shifts. Second, the sharp disturbances that have rocked many transition countries suggest using the model proposed by Perron and Rodríguez (2003) to test for unit-root in the presence of additive outliers; Zivot and Andrews (1992) models for unit-root tests are modified to allow for outliers detected by the Perron and Rodríguez (2003) procedure. Third, for comparison to panel tests on developed countries' real exchange rates, and in some cases developing countries real rates, this paper also uses panel unit-root tests based on SUR techniques.

In the remainder of this paper, Section 2 presents illustrations of the importance of using specifications that allow for structural shifts and outliers in unit-root tests of CEE transition economies' 
real exchange rates, and also gives a survey of the literature on mean-reversion tests of real exchange rates. Single-equation unit-root tests for real exchange rates are outlined in Section 3, while Section 4 discusses panel unit-root tests. Section 5 describes the data and presents test results for monthly data on CEE-10 real exchange rates relative to the U.S. dollar and also relative to the Euro. Section 6 discusses the half lives of real-rate disturbances in transition countries. Section 7 summarizes and draws conclusions.

\section{Parameter Shifts and Outliers in Transition Economies; Previous Unit-Root Tests}

This paper presents unit-root test results for a variety of test-equation specifications. As Perron (1989), Zivot and Andrews (1992), Perron and Rodríguez (2003) and others demonstrate, a unitroot test must use the specification the data require, including allowing for parameter shifts ant outliers, if the test is to have the stated size and if the test's power is to be optimized. In contrast, conventional unit-root tests - for example, ADF tests - assume that the process's mean and time trend are constant, and any outliers are insufficiently important to distort the tests. In addition to these size and power issues, this paper addresses the fact that the specification must be appropriate to the data in order to reduce bias in key parameter estimates, in this paper, the speed of mean reversion.

Consider two illustrations. The data in Figure 1 suggest there was a sharp change in Bulgaria's mean real exchange rate at approximately the start of 1997, and just after, a large outlier. In fact, in the face of a grave economic and financial crisis "the socialist government resigned in December 1996, and a reform-minted caretaker government was established to resolve the crisis..." (IMF (2004), p. 8, point 10) corresponding to mean shift and outlier. Otherwise the real exchange rate appears to show mean reversion on either side of the shift and outlier. ${ }^{1}$ As seen in Section 5 , if the unit-root tests do not allow for the mean shift and the outlier, the data can reject the unit-root null at the $10 \%$ (Table 4). If the tests allow for the mean shift and the outlier, however, the data can reject the null at the $1 \%$ level (Tables 9,12$) ;^{2}$ aside from the mean shift and the outlier, Bulgaria's real exchange rate shows mean reversion.

The data in Figure 1 for Estonia appear to show a substantial negative mean rate of change in the real exchange rate (real appreciation, as the real exchange rate is defined in Section 3) until say 1997, with perhaps a zero mean rate of change thereafter, but otherwise mean-reverting deviations. In fact, in June, 1991, when Estonia adopted the kroon and pegged it to the Deutsche Mark

\footnotetext{
${ }^{1}$ The data also show a more minor spike corresponding to "a first currency crisis in late 1993-early 1994..." (IMF (2004), p.7, point 7).

${ }^{2}$ In Table 7 , with a shift in trend but no outlier, the data can also reject the unit root null al the $1 \%$ level. The most satisfactory model in terms of speed of adjustment and the standard error of the regression, is in Table 12, with mean and trend shifts and an outlier.
} 
through a currency board, Estonia central bank officials expected a period of real-rate appreciation as gradual decontrol of non-tradable prices would cause the domestic price level to rise. As seen in Section 5, if the unit-root tests do not allow for a mean shift, the data can nevertheless reject the unit-root null at $2.5 \%$ level (Table 4), but the estimated speed of adjustment is very slow as compared to estimates in other specifications. In tests that allow for a mean shift, the data more strongly reject the null (at the 1\% level-Table 5), and the estimated speed of adjustment is substantially faster $-8.90 \% /$ month versus $4.63 \% /$ month. $^{3}$

From Figure 1, it appears that the other two Baltic countries, Latvia and Lithuania, may also require specifications that allow for mean shifts. Further, it appears that Romania and possibly Slovakia may require specifications that allow for outliers.

Previous Tests of Mean-Reversion in Real Exchange Rates. For developed-country data from the post-Bretton Woods era, Messe and Rogoff (1988) and Nelson (1990) cannot reject the unit-root null using single-equation methods for real exchange rates. Largely because of the low power of single-equation techniques when the root is close to unity, much of the later literature focuses on panel tests. O'Connell (1998) cannot reject the unit-root null using GLS techniques on panels that include both developed- and developing-country data. Using panel methods with GLS techniques on developed-country data, Papell and Theodoridis (1998) find week but increasing evidence in favor of PPP as the sample period lengthens. In contrast, Abuaf and Jorion (1990), Jorion and Sweeney (1996), Papell (1997), Sarno and Taylor (1998) and Higgins and Zakrajšek (1999) find the data can reject the unit-root null in panel tests with SUR techniques on developedcountry data. ${ }^{4} 5$

The literature discussed above makes no allowance for structural shifts or large outliers. ${ }^{6}$ Some papers, however, detect the need to allow for parameter shifts in real exchange rate processes. In analyzing long annual data series, from 90 to 200 years, Hegwood and Papell (1998) conclude that standard unit-root tests are too restrictive adequately to test real exchange rates when data series contain structural breaks, and they find strong mean reversion when breaks are accounted for. Using the Lee (1976) and Lothian and Taylor (1995) data sets, they argue that the real exchange rate is stationary around a mean that experiences occasional structural shifts. Related to this paper's results, Hegwood and Papell (1998) also estimate substantially faster adjustment speeds in specifications allowing for mean shifts.

Some economists argue that real exchange rate time-series models may require time trends. Papell and Prodan (2003) find evidence of mean reversion around time trends in four out of 18

\footnotetext{
${ }^{3}$ When a time trend is also included (Table 6) the estimated speed of adjustment is $14.0 \% /$ month.

${ }^{4}$ Some papers, for example, Wu (1996) and MacDonald (1996), use fixed-time effects rather than SUR methods. Fixed-time effects are not adequate, however, for real exchange data.

${ }^{5}$ Sweeney (2005) applies SUR to G-10 countries' log nominal exchange rates relative to the dollar during the current float and rejects the unit-root null with significance levels form the $0.5 \%$ to $15 \%$ across sample periods.

${ }^{6}$ Jorion and Sweeney (1996) allow for mean and trend shifts in monthly data for G-10 countries from 1974 to 1993 , but find that the shifts are usually not significant or are not needed to reject the unit-root null.
} 
countries' real exchange rates. Obstfeld (1993) models such trends as arising from the BalassaSamuelson effect (Balassa (1964), Samuelson (1964)). ${ }^{7}$ In results below, inclusion of time trends often reduces the standard error of the regression and increases the estimated speed of adjustment of a given currency.

\section{Single-Equation Unit-Root Tests for the Real Exchange}

\section{Rates}

The real exchange rate is calculated as

$$
r_{t} \equiv s_{t}+p_{t}^{*}-p_{t}
$$

where $s_{t}$ denotes the logarithm of the nominal exchange-rate (the domestic-currency price of foreign currency) at time $t ; p_{t}^{*}$ and $p_{t}$ are the logs of foreign and domestic price-levels. ${ }^{8}$ Testing for PPP is equivalent to testing for a unit-root in the real exchange-rate against the stationary alternative. In the simplest unit-root tests, the estimating equation is based on:

$$
\Delta r_{t}=\mu+\alpha r_{t-1}+\varepsilon_{t}
$$

where $\varepsilon_{t}$ is a sequence of independent normal random variables with mean zero and variance $\sigma^{2}\left(\varepsilon_{t} \sim \operatorname{iid}\left[0, \sigma^{2}\right]\right)$. Under the unit-root null, $\alpha=0$ and $\mu>/<0$; if $\mu \neq 0$, then the real exchange rate is a random walk with drift, or contains a time trend with slope equal to $\mu$. Under the alternative hypothesis of mean reversion, $-1<\alpha<0$, the long-run real exchange rate is $\mu /(1+\alpha)$ and $-\alpha>0$ is the real rate's speed of adjustment to its long-run level. A necessary condition for long-run PPP is that $r_{t}$ be stationary, or $r_{t}$ is not driven by permanent shocks.

A more general model allows for trend stationary, as in

$$
\Delta r_{t}=\mu+\beta t+\alpha r_{t-1}+\varepsilon_{t}
$$

\footnotetext{
${ }^{7}$ A number of economists investigate Balassa-Samuelson effects in transition economies, though they report mixed empirical evidence; Égert (2004) provides a survey of the arguments and evidence.

${ }^{8}$ Engel (2000) and Ng and Perron (2002) use a somewhat different approach to analyzing the real exchange rate. They decompose the real exchange rate into two components:

$$
r_{t}=x_{t}+y_{t}
$$

$x_{t}$ is traded-goods component; $y_{t}$ captures the bilateral differences between the relative price of traded to non-traded goods. The logarithm national price level of home country is $p=(1-\lambda) p^{T}+\lambda p^{N}$, where $p^{T}$ is the log price of tradedgoods, $p^{N}$ the log price of non-traded goods, and $\lambda \in(0,1)$. The traded-goods component is $x_{t}=s_{t}+p_{t}^{T *}-p_{t}^{T}$ and $y_{t}=\lambda^{*}\left(p_{t}^{N *}-p_{t}^{T *}\right)-\lambda\left(p_{t}^{N}-p_{t}^{T}\right)$; foreign country variables are denoted with an asterisk. If both components are stationary, or are non-stationary but appropriately cointegrated, then real exchange rate is stationary. According to early studies, the traded goods component is stationary, or PPP holds for traded goods. Engel (2000) and Ng and Perron (2002) investigate whether non-stationarity for the second component affects real exchange rate stationarity. Furthermore, Engel (2000) argues that unit-root tests might fail to detect a non-stationary component in real exchange rates. Ng and Perron (2002) argue that unit-root tests of the components are neither necessary nor sufficient for establishing unit-root in real exchange rate.
} 
Under the alternative, $-1<\alpha<0$; if $\beta \neq 0$, the equilibrium real rate contains a time trend, but the real rate reverts to the trend equilibrium rate. Furthermore, it is common to allow for serial correlation in $\Delta r_{t}$ by including $k$ lagged values of $\Delta r_{t}$, giving an Augmented Dickey-Fuller regression,

$$
\Delta r_{t}=\mu+\beta t+\alpha r_{t-1}+\sum_{i=1}^{k} \gamma_{i} \Delta r_{t-i}+\varepsilon_{t}
$$

$k$ can be determined using the selection procedure Perron (1989) suggests: Choose some maximum value $k_{\max }$ and work backward from $k=k_{\max }$, selecting $k$ such that the t-statistic for $\left|\gamma_{i}\right|$ is greater than 1.6.

A number of economists show that valid unit-root tests must take account of parameter instability. Perron (1989) shows that if $-1<\alpha<0$ but there is a one-time shift in either $\mu$ or $\beta$ in (2), (3) or (4) that is not accounted for in estimation, then conventional tests are biased against rejecting the unit-root null. To allow for one shift in the intercept and/or time trend, (4) can be revised as

$$
\Delta r_{t}=\left[\mu+\theta D_{\mu, t}\right]+\left[\beta t+\phi D_{\beta, t}\left(t-T_{\beta}\right)\right]+\alpha r_{t-1}+\sum_{i=1}^{k} \gamma_{i} \Delta r_{t-i}+e_{t}
$$

$D_{\mu, t}$ is a dummy, equal to zero for $t<T_{\mu}$ and equal to unity for $t \geq T_{\mu}$, where $T_{\mu}$ is the time at which the intercept shifts. $D_{\beta, t}$ is a dummy, equal to zero for $t<T_{\beta}$ and equal to unity for $t \geq T_{\beta}$, where $T_{\beta}$ is the time at which the trend coefficient shifts. ${ }^{9}$

In addition to shifts in intercept and trend coefficient, other economists investigate the effect on unit-root tests of additive outliers in the data. (5) may be modified to include $m$ outliers, as in

$$
\Delta r_{t}=\left[\mu+\theta D_{\mu, t}\right]+\left[\beta t+\phi D_{\beta, t}\left(t-T_{\beta}\right)\right]+\sum_{i=0}^{p+1} \sum_{h=1}^{m} \delta_{i, h} D_{h, t-i}+\alpha r_{t-1}+\sum_{i=1}^{k} \gamma_{i} \Delta r_{t-i}+\varepsilon_{t}
$$

The lagged dummy variables are included to remove outlier effects on real appreciation. If the additive outlier $h$ occurs at time $T_{a o, h}$, then the model requires a dummy equal to unity for $T_{a o, h}$ and for the next $k$ periods because of the ADF lag structure, with the dummy equal to zero otherwise.

Below, specialized versions of the general model in (6) are tested. In Break Model 1, the timetrend coefficients are set to zero, $\beta=0$ and $\phi=0$, but $\mu, \theta, \alpha, \gamma_{i}$ and $k$ are fit freely, and one shift in $\mu$ is allowed. (Papell (1997) and others argue that real rates should not contain time trends.) Break Model 2 allows for one shift in $\mu$, but includes a time trend though without shift in trend, $\beta \neq 0$ and $\phi=0$. Break Model 3 allows for one shift in $\beta$. Break Model 4 allows for one shift in $\mu$ and one shift in $\beta$ at the same time, denoted $T_{b}$.

\footnotetext{
${ }^{9}$ Some researchers define long-run PPP as requiring rejection of the unit-root hypothesis and acceptance of the hypothesis of no breaks in mean or trend. In contrast, Dornbusch and Vogelsang (1991) define qualified purchasing power parity (Q-PPP) as rejection of the unit-root hypothesis and acceptance of the alternative of stationary after the allowing for one change in the intercept. Papell and Prodan (2003) define trend qualified purchasing power parity (TQ-PPP) as rejection of unit-root null in favor of the alternative of trend stationarity with a structural change in trend at some unknown point; Hegwood and Papell (1998), however, define quasi purchasing power parity as both rejection of the unit-root hypothesis and rejection of the no-trend-break hypothesis.
} 
Perron (1989) finds $T_{\mu}, T_{\beta}$, and $T_{b}$ by identifying events before examining the data (for example, the Great Depression and the oil shock of 1973-74). Most often, economists now find $T_{\mu}, T_{\beta}, T_{b}$, $T_{a o, h}$ endogenously, as part of the estimation. Zivot and Andrews (1992) extend Perron's (1989) methods for unit-root tests and develop a procedure for detecting when structural change most likely occurs. They endogenously estimate one breakpoint for each series; Lumsdaine and Papell (1997) extend these tests to allow for two breaks.

The goal is to test the null hypothesis against the alternative of stationarity with structural change(s) at some unknown point. Assuming that $\Lambda=\left[\lambda_{0}, 1-\lambda_{0}\right] \subseteq(0,1)$, then $\left[\left[\lambda_{0} T\right], T-\left[\lambda_{0}\right] T\right]$ is the interval believed to contain the true break fraction. Zivot and Andrews (1992) suggest running regressions for (6) by OLS, without outliers, where the breakpoint for $\mu$ or $\beta$ is obtained for $T_{j}=\overline{2, T-1}, j=\{\mu, \beta, b\}$ (or $\left[\lambda_{0} T\right],\left[\lambda_{0} T\right]+1, \cdots, T-\left[\lambda_{0} T\right]$ ). Following Zivot and Andrews (1992), $\hat{T}_{j}$, is chosen such that

$$
t_{\hat{\alpha}}\left(\hat{T}_{j}\right)=\min _{2<T_{j}<T-1} t_{\alpha}\left(T_{j}\right), \quad j=\{\mu, \beta, b\}
$$

In addition to possible break points in mean or trend, many time series of transition-country real exchange rates appear to display one or more outliers. Franses and Haldrup (1994) and Shin et al. (1996) show that the presence of additive outliers in a univariate time series affects the limiting distribution of Dickey-Fuller unit-root test statistics. Vogelsang (1999) proposes two procedures for unit-root testing when additive outliers may be present; Perron and Rodríguez (2003)'s simulations validate a method which has considerably more power than Vogelsang (1999) and is therefore used here. Perron and Rodríguez (2003) suggest a detection-procedure based on the regression:

(8) $\Delta r_{t}=\hat{\delta}\left(D_{a o, t}-D_{a o, t-1}\right)+\hat{u}_{t}$,

where $D_{a o, t}=\mathbf{1}\left(t=T_{a o}\right)$, otherwise 0 . The presence of an additive outlier can be tested using $\tau_{d}=\sup _{T_{a o}\left|t_{\hat{\theta}}\left(T_{a o}\right)\right|}$. If $\tau_{d}$ exceeds the critical value, then an outlier is detected where $\hat{T}_{a o}=$ $\max _{T_{a o}\left|t_{\hat{\theta}}\left(T_{a o}\right)\right|}$. ( They give the critical values for $\tau_{d}$ in their Table IV.) Unless the data demand multiple outliers, they suggest stopping after detecting one outlier; with more outliers, the loss in degrees of freedom in ADF-regressions can be severe when $k$ is large. An appendix available from the authors provides the details of how exact critical values from simulation were found for the various single-equation models.

\section{Panel Models}

Literature using panel unit-root tests has seen a recent upsurge. Panel data methods can ameliorate the low-power problem against near-unit-root alternatives in the standard ADF test for short data spans. From Levin and Lin (1992) panel unit-root tests,

$$
\Delta r_{j, t}=\mu_{j}+\alpha r_{j, t-1}+\sum_{i=1}^{k} \gamma_{j, i} \Delta r_{j, t-i}+\varepsilon_{j, t}
$$


where $\varepsilon_{j, t} \sim \operatorname{iid}\left[0, \sigma^{2}\right]$ for all $j, E\left[\varepsilon_{j, t} \varepsilon_{j, t}^{\prime}\right]=\sigma^{2} I_{N}$, and $I_{N}$ is the identity matrix. The nullhypothesis, that real exchange rates contain unit roots implies that $\alpha=0$; in the absence of time trends, $\mu_{j}=0$ for all $j$. The alternative hypothesis implies that $\alpha<0$; innovations decay at the rate $\alpha .^{10}$

Because real exchange rates display substantial contemporaneous cross-correlations, Levin and Lin (1992)'s panel unit-root test suffers from substantial upward size-distortion (see for example O'Connell (1998)'s discussion). To avoid this problem, a number of researchers use SUR panel techniques, as Section 2 discusses. Though few researchers have done so, SUR techniques can be extended to systems of ADF equations with one break in mean and/or trend for each country. This extension is applied below to the ten CEE transition countries' real exchange rates.

This paper thus uses the following ADF systems, based on (5) above:

$$
\Delta r_{j, t}=\left[\mu_{j}+\theta_{j} D_{\mu_{j}, t}\right]+\left[\beta_{j} t+\phi_{j} D_{\beta_{j}, t}\left(t-T_{\beta_{j}}\right)\right]+\alpha r_{j, t-1}+\sum_{i=1}^{k_{j}} \gamma_{j, i} \Delta r_{j, t-i}+\varepsilon_{j, t} .
$$

Note that this model does not take account of outliers. ${ }^{11}\left\{r_{j, t}\right\}_{t=1}^{T}$ denotes the time-series of the logarithm of the real exchange-rate for country $j, \varepsilon_{j, t} \sim N I D\left[0, \sigma_{j}^{2}\right]$ for all $j$, and $E\left[\varepsilon_{j, t} \varepsilon_{j, t}^{\prime}\right]=\Omega_{S U R}$. This approach is a generalization of Levin and Lin (1992) and Levin et al. (2002). Furthermore, SUR is more efficient than ordinary least-squares because it takes into account the correlation of the residuals. The ADF estimating-systems proposed here allow for country-specific intercepts $\left(\mu_{j}\right)$ and different higher-order dynamics $\left(\gamma_{j, i}, k_{j}\right)$. Following Levin and Lin (1992), a common speed-of-adjustment coefficient is imposed across countries $\left(\alpha_{j}=\alpha\right)$.

If the DGP for real exchange-rates in transition countries contains a linear trend, then the unit-root null would imply $\theta_{j}=0, \beta_{j}=0, \phi_{j}$, and $\alpha=0$ for all $j$, while the stationary alternative would implies $\alpha<0$ with $\mu_{j}, \theta_{j}, \beta_{j}$, and $\phi_{j}=0$ fitted freely. In the present case, under the alternative hypothesis, the real exchange rates for transition economies are stationary around a country-specific deterministic trend with structural changes.

Using the SUR panel test, all the parameters in the system of ten equations were estimated simultaneously, including the parameter contained in the contemporaneous cross-sectional covariancematrix $\Omega_{S U R}$, which determines temporal dependence among innovations in the real exchange-rates. Sweeney (2005) proves that the asymptotic results in Levin and Lin (1992) hold under SUR, but he does not consider mean and time-trend and breakpoints. The present study used the breaks and $k_{j}$ for each country as found from the single-country regressions discussed in Section 3.

\footnotetext{
${ }^{10}$ See also Levin et al. (2002)(LCC). LCC, a revision of LL(1992,1993), give a more elegant proof and a superior discussion, with references to important results in Phillips and Moon (1999) for the case where $T \rightarrow \infty$ and $n \rightarrow \infty$ simultaneously, rather than the more common and tractable case where $T \rightarrow \infty$ and then $n \rightarrow \infty$ sequentially. Note that instead of using the asymptotic t-statistic in the text above (from LL), LLC normalize it to make it $N[0,1]$.

${ }^{11}$ In these panels, tests often rejected the null that the residuals were normal. Dummy variables were parsimoniously introduced to make the residuals approximately normal in order to satisfy panel unit-root test assumptions. After this procedure, there was not need to allow for outliers. Introducing dummies to make the residuals approximately normal had little effect of the t-value of the slope on the lagged real rate, but increased the half-life modestly.
} 
Below, specialized versions of the general model in (9) are tested. In Panel Break Model 1, the time-trend coefficients are set to zero for each country, $\beta_{j}=0$ and $\phi_{j}=0$, but $\mu_{j}, \alpha, \gamma_{j, i}$ and $k_{j}$ are fit freely, and one shift in each of $\mu_{j}$ is allowed. Panel Break Model 2 allows for one shift in $\mu_{j}$; it contains a time trend but no shift in trend, $\beta_{j} \neq 0$ and $\phi_{j}=0$. Panel Break Model 3 allows for one shift in $\beta_{j}$. Panel Break Model 4 allows for one shift in $\mu_{j}$ and one shift in $\beta_{j}$ at the same time, denoted $T_{b_{j}}$.

Critical values for SUR estimations were found by Monte Carlo simulation. The data generating process for errors in (9) is assumed $\varepsilon_{j, t} \sim N\left[0, \Omega_{S U R}\right]$, where $\Omega_{S U R}$ is non-diagonal and positive definite, instead of $\varepsilon_{j, t} \sim N[0, I]$ as in Levin and Lin (1992). The literature suggests three possible DGPs for $r_{j, t}$ :

$$
\begin{aligned}
& \left(D G P_{1}\right) \quad \Delta r_{j, t}=\varepsilon_{j, t} \\
& \left(D G P_{2}\right) \quad \Delta r_{j, t}=\sum_{i=1}^{k_{j}} \hat{\gamma}_{j, i} \Delta r_{j, t-i}+\varepsilon_{j, t} \\
& \left(D G P_{3}\right) \quad \Delta r_{j, t}=\hat{\mu}_{j}+\sum_{i=1}^{k_{j}} \hat{\gamma}_{j, i} \Delta r_{j, t-i}+\varepsilon_{j, t}
\end{aligned}
$$

where $\varepsilon_{j, t} \sim N\left[0, \Omega_{S U R}\right]$, and $\hat{\mu}_{j}$ and $\hat{\gamma}_{j, i}$ are estimated values for each country $j$. Im et al. (1997) suggest DGP 1 , O'Connell (1998) and Papell (1997) suggest DGP ${ }_{2}$, and Sarno and Taylor (1998) suggest $\mathrm{DGP}_{3}$. Sweeney (2005) discusses the choices in term of size and power; based on his discussion, $D G P_{1}$ is used here. Furthermore, the sample covariance-matrix of $\Delta r_{j, t}, \Omega_{\text {sample }}$, is used as an estimator of $\Omega_{S U R}$.

Simulations were done as follows. First, the variance-covariance matrix of the first differences of the $N$ time-series, $\left\{r_{j, t}\right\}_{t=1}^{T}$, was computed. Then $T \times N$ random numbers were drawn using the variance-covariance matrix from the sample. Third, the generated random-numbers $\varepsilon_{j, t}, i=\overline{1, N}$, $t=\overline{1, T}$, were added to obtain $N$ random walks with $T$ observations each. Fourth, the systems (9) for Panel Break Models 1-4 (as discussed above) were estimated using simulated time-series and the $t_{\alpha}$ were computed. Repeating steps 1-4 for 5,000 replications yielded the distribution of $t_{\alpha}$ under the null hypothesis $\alpha=0$.

\section{Empirical Results for Real Exchange Rates in the CEE-10}

This section presents empirical results from transition countries for unit-root tests for real exchange rates constructed from monthly nominal exchanges rates, and consumer and producer price indexes (CPIs and PPIs). The methods are described in Sections 3 and 4. Ten CEE countries are included in the analysis: Bulgaria, the Czech Republic, Estonia, Hungary, Latvia, Lithuania, Poland, Romania, Slovakia, and Slovenia. CPI, PPI and U.S. dollar data are from International Financial Statistics (CD-ROM April 2005); Euro exchange rates are from the Vienna Institute of International Economic Studies database and the national central banks for the Baltic countries. ${ }^{12}$

\footnotetext{
${ }^{12}$ European Monetary Union currencies were locked into the Euro on January 1, 1999. Before that date, the Euro exchange rates are calculated as weighted averages of the EMU exchange rates.
} 
The sample period generally starts in 1993:01 and always ends in 2003:12. ${ }^{13}$ Figure 1 illustrates the evolution of real exchange rates during the sample period for CPIs with the USD as the base currency.

Descriptive statistics for levels and first differences of real exchange rates are in Table 2 for CPIs with the USD base currency; comparable tables for PPIs are available from the authors, as are tables with the Euro as base currency and the German CPI as the base price level. ${ }^{14}$ Table 3 gives a summary of which single-equation models are have significant slopes on the lagged log real exchange rate. For CPIs, in the five models without outliers 24 of the 50 models have significant slopes when the USD is the base currency, 27 of 50 when the Euro is the base currency, and 19 of 50 for PPIs with the USD as the base. (For the 40 break models with outliers, the numbers of significant cases of 9,13 , and 8 , respectively.) The results for the case where the USD is the base currency are discussed in some detail, and this paper includes tables for these results; tables for other experiments are available from the authors.

\subsection{Single-Equation Unit-Root Tests for Real Exchange Rates}

Each country's real exchange rate was tested for a unit root with all nine single-equation models in Section 3. Table 3 summarizes the results. For the ADF model and the four break models, in at least some of these models, the data reject the null for eight of ten CEE countries - Bulgaria, Estonia, Hungary, Latvia, Lithuania, Poland, Romania and Slovenia. For the Czech Republic, in three of the four break models with outliers the data reject the unit-root null.

For Slovakia, the data cannot reject the null in any of the nine models considered. In earlier experiments for the sample period 1993:01 to 2002:05, however, the data could reject the null for Slovakia in three of the nine models (Break Model 2 and 3, and Break Model 3 with outliers); the half-lives ranged from 3.49 to 3.58 years. This illustrates that the models can be sensitive to the sample period used.

Consider results for the ADF and the four break models. For Bulgaria, Estonia, and Latvia, the data reject the null for four of the five models, for Poland and Romania in three models each, and for Lithuania, Hungary, and Slovenia, in two models each. For a given country, however, comparisons across Tables $4-8$ make it clear that the various models differ a good deal in how adequately they fit the data. For purposes of discriminating across models, focus on the estimated slope of the lagged real exchange rate and on the standard error of the regression (SER).

In the ADF model without shifts, the data reject the null for six countries (Table 3) - Bulgaria, Estonia, Latvia, Lithuania, Poland and Romania. For each country, however, other models are clearly more adequate than the standard ADF model. For Bulgaria, the slope is the largest in

\footnotetext{
${ }^{13}$ For Euro experiments, data begin in 1995:01 for Latvia and 1994:01 for Lithuania. For PPI experiments, data begin in 1995:01 for Bulgaria and Slovenia, and 1994:01 for Estonia and Lithuania.

${ }^{14} \mathrm{An}$ alternative approach is to use a weighted average of the EMU-country CPIs.
} 
absolute value in Table 6 (Break Model 2, where a shift in mean is allowed for and a trend is included), though the SER is slightly smaller in Table 5 (Break Model 1). For Romania the model allowing for a shift in mean and no time trend (Table 5, Break Model 1) gives the largest slope in absolute value (though the SER is slightly small for Break Model 4).

For Romania, the data are well fit and reject the null at the $1 \%$ level when a shift in mean is allowed in Table 5 (Break Model 1), but if a time trend is also included as in Table 6 (Break Model 2), the data cannot reject the null. The data demand a mean shift for Estonia (Table 5, Break Model 1), but are notably better fit if a time trend is also included (Table 6, Break Model 2). The data for Poland clearly require a shift in mean, but are also better fit if a time trend is also included (Table 5 versus Table 6).

Single-Equation Models Allowing for Outliers. Tables 9 - 12 show the cases where the data reject the unit-root null in break models that include outliers. The importance of model specifications that allow for outliers is demonstrated by the fact that for the Czech Republic the data can reject the unit-root null only in models which include outliers.

The break models with outliers reject the unit-root null for only two other countries, Bulgaria and Hungary, but the data can reject the unit-root null for these countries even if the models do not include outliers. For Bulgaria, three of four break models with outliers reject the unit-root null, but as judged by estimated slopes on the lagged real rates and the SERs, including the outliers is not really necessary (though Break Model 4 with outliers gives the smallest SER). For Hungary, Break Model 4 rejects the null with or without outliers, but inclusion of the outlier increases the absolute value of the slope from 0.205 to 0.217 and thus raises the estimated adjustment speed.

In the discussion of half-lives below, these results are compared with those for the case where CPIs and the Euro are used, and for the case where PPIs and the USD are used.

\subsection{Panel Models}

For various lags $k=1,2,3,9$, Table 13 presents SUR panel test results as measured by the processes' half lives (discussed below). Results are reported for the ADF model and for all four Break Models. The null hypothesis $\alpha=0$ can be rejected at the $1 \%$ significance-level for all $k$. On the one hand, as $k$ increases, the t-statistic of $\alpha$ decreases in absolute value, as might be expected with the increases in the number of estimated parameters. On the other hand, an increase in $k$ is associated with a rise in the estimate of $|\alpha|$, and thus with an increase in the estimated speed of adjustment, as shown by the decrease in the half life of adjustment. (The half-life varies inversely with the speed of adjustment $|\alpha|$, as in Section 6 discusses.) Break Models 2, 3, and 4 give very roughly the same half lives. As can be seen, allowing for the possiblity of outliers is not needed to allow these SUR panel unit-root tests to reject the null.

Table 13 also presents SUR panel test results where the $k$ is chosen separately for each county 
and are thus more flexible. In each case the null can be rejected at the $1 \%$ significance level. The half lives are sometimes larger, sometimes smaller for the case where the $k$ are chosen separately versus the case where $k=9$ for all countries.

Are Some Real Exchange Rates I(1)? Karlsson and Löthgren (2000) emphasize that in panel tests the rejection of the unit-root null is not sufficient to conclude that all series are stationary. From above, however in single-equation tests for the USD as the base currency, all currencies save Slovakia's appear to be stationary, and for the Euro as the base currency all currencies appear to be stable. ${ }^{15}$

\section{$6 \quad$ Half Lives}

The half life of a process is an intuitive measure of the speed of adjustment; originally from physics, it measures the decay of a substance comprised of a large number of identical particles. Half life is the time it takes for any amount of the substance to decay to half. The half lives in the models considered here is

$$
H=-\frac{\ln 2}{\ln (1+\alpha)} .
$$

Single-Equation Models: Half-Lives with Dollar Exchange Rates and CPIs. From the results reported above, it can be shown that failure to allow for structural shifts and outliers, when the data demand them, causes downward bias in estimates of the speed of adjustment, that is, upwards bias is estimates of half lives. ${ }^{16}$ Table 14 reports on half lives for single-equation-models with significant results in the nine models in Tables 4 - 12. Half lives estimated by the standard ADF unit-root test (Table 4) tend to be very high, as shown in Table 14; real exchange-rate shocks took between 14.6 years to be reduced to half for Estonia, and 5.1 years for Bulgaria.

Minimum half lives across all significant single-equation models in Section 5 were over 1.5 years: The lowest minimum (1.58) was estimated for Bulgaria in Break Model 2, and the highest minimum (7.42) for Lithuania in Break Model 2. As Table 14 shows, including structural changes and outliers in the models yields substantially reduced half-life estimates. This paper's single-equation-model estimates, with an average of minimum half-lives of 4.19 years, ${ }^{17}$ are consistent with other research that shows that real-exchange-rate shocks generally take 3-5 years to be reduced by half.

\footnotetext{
${ }^{15}$ Another approach to investigating the number of rates which are $\mathrm{I}(0)$ is to use a Johansen (1988) Likelihood Ratio (JLR) test. Sarno and Taylor (1998)), for example, use a JLR test for this purpose on four real exchange rates, but their models do not contain shifts in mean or trend, or outliers, nor does Johansen (1988) allow for these. Test in papers Johansen et al. (2000),Saikkonen and Lütkepohl (2000) Lütkepohl et al. (2004) allow for the case where the data contain shifts in trend or level, or outliers, but are too rigid to be appropriate for present purposes. These papers' models assume that mean shift, say, in one country must be parametrized as showing up in all countries, and similarly with trend shifts or outliers; this leads to disastrous collinearity if more than one or two shifts or outliers are allowed, and hence very imprecise model estimates.

${ }^{16}$ As is well known, the estimated speed of adjustment from unit-root test equations is biased down. Failure to allow for structural shifts and outliers, when the data contain them, causes greater downward bias in the estimated speed of adjustment, and thus greater upward bias in estimated half life.

${ }^{17}$ It might be noted that in the absence of the three Baltic countries, the average half-life is 3.19 years.
} 
Single-Equation Models: Half-Lives with Euro Exchange Rates and the German $\boldsymbol{C P I}$. There are two key results. First, the data for Slovakia can reject the null in six of the nine models fit (see Table 3). What is more, the minimum half-life for Slovakia is only 1.24 years. Second, the average of the minimum-half lives is only 1.98 years, as opposed to 4.19 years for the dollar and CPIs. It is notable that the data cannot reject the null for any ADF model, whereas they can for six countries in Table 14. Further, these data can reject the null for Break Model 4 for all countries save Hungary, whereas they can only for Bulgaria, Hungary and Romania in Table 14.

Single-Equation Models: Half-Lives with the Dollar and PPIs. The average minimum half-life is 4.00 years, as opposed to 4.19 years for the dollar and CPIs or to 1.98 years for the Euro and German CPI. 33 models reject for the dollar and the CPIs, but 27 for the dollar and PPIs (Table 3). Nine break models with outliers reject for the USD and the CPIs, and eight for the USD and the PPIs.

Panel Models: Half-Lives with the Dollar and CPIs. Table 13 above presents half-lives implied by SUR panel estimates. For ADF models, without time trends or structural shifts in mean, half-lives range from 12.87 years to 14.87 years. Estimates from Panel Break Models all implied lower half lives. For $k=9$ for each country, and for $k$ chosen individually for each country, the half lives are very roughly the same for Break Models $2-4$.

The difference between half-lives in panel models and the average half-life for single-equation models is striking. Intuitively, this appears to arise from the fact that the panel models all require each currency to have the same model, but the single-equation models show that the data demand very different models across currencies.

\section{Summary and Conclusions}

This paper reports single-equations and panel unit-root tests for real exchange rates of ten Central and Eastern European (CEE) transition economies. It makes three main contributions. First, the unit-root tests presented here differ from the previous empirical literature on CEE real exchange rates by allowing for structural changes and outliers in the transition-country real exchange rates. Second, the study presents both single-equation and panel test results for transition countries. Third, this paper documents pays attention to the way that incorrect model specification biases downward the estimated speed of real rate adjustment and biases upwards real rates' half-lives.

In previous single-equation unit-root tests on non-transition countries, many studies report the data are unable to reject the unit-root null; researchers commonly note, however, that standard single-equation unit-root tests have low power against local-stationarity alternatives in small samples. In this paper, when single-equation-test specifications allow for structural shifts and for 
outliers, the data reject the unit-root null for all ten transition countries, often at the $1 \%$ significance level.

If neither structural changes nor outliers are taken into account, the unit-root hypothesis is rejected in some of this paper's single-equation tests. In these cases, however, the estimated speed of mean reversion is very slow; half lives are often over ten years. Using test-equation specifications that allow for structural shifts and for outliers, the estimated speeds of adjustment are much faster; estimated half lives tend to be 3-5 years, similar to results in previous work that finds mean reversion in real exchange rates in major industrialized countries.

The paper also reports on SUR panel unit-root tests for transition-country real exchange rates. Some tests do not allow for structural shifts but others do (outliers are not allowed for). In all sets of panel tests, the data strongly reject the unit-root null at the $1 \%$ significance level. 


\section{References}

N. Abuaf and P. Jorion. Purchasing power parity in the long run. Journal of Finance, 45:157-174, 1990.

B. Balassa. The purchasing -power parity doctrine: a reappraisal. Journal of Political Economy, $72(6): 584-596,1964$.

F. Coricelli and B. Jazbec. Real exchange rate dynamics in transition economies. Technical report, Discussion Paper No. 2869, Center for Economic Policy Research, 2001.

M. De Broeck and T. Sløk. Interpreting real exchange rate movements in transition countries. Technical report, Discussion Paper No. 7, Bank of Finland Institute for Economies in Transition BOFIT, 2001.

S. Dibooglu and A. Kutan. Sources of real exchange rate fluctuations in transition economies: The case of poland and hungary. Journal of Comparative Economics, 29:257-275, 2001.

R. Dornbusch and T. J. Vogelsang. Real Exchange Rates and Purchasing Power Parity, chapter Trade Theory and Economic Reform: North, South, and East, Essays in Honor of Bela Balassa, pages 3-24. Basil Blackwell, 1991.

B. Égert. Assessing equilibrium exchange rates in cee acceding countries: Can we have deer with beer without feer? Working paper 664, The William Davidson Institute, February 2004.

C. Engel. Long-run ppp may not hold after all. Journal of International Economics, 57:243-273, 2000.

S. Fischer and R. Sahay. The transition economies after ten years. Working paper 7664, NBER, April 2000.

P. H. Franses and N. Haldrup. The effects of additive outliers on tests for unit roots and cointergration. Journal of Business and Economic Statistics, 12:471-478, 1994.

K. Hadri. Testing for stationarity in heterogeneous panel data. The Econometrics Journal, 3: $148-161,2000$.

L. Halpern and Ch. Wyplosz. Economic transformation and real exchange rates in the 2000s: the balassa-samuelson connection. UNO Economic Survey of Europe, 1:227-239, 2001.

N. Hegwood and D. Papell. Quasi purchasing power parity. International Journal of Finance and Economics, 3:279-289, 1998. 
M. Higgins and E. Zakrajšek. Purchasing power parity: Three stakes through the heart of the unit root null. Technical report, Federal Reserve Bank of New York, June 1999.

K. S. Im, H. M. Pesaran, and Y. Shin. Testing for unit roots in heterogeneous panels. Working Paper, Cambridge University, 1997.

IMF. Bulgaria: Ex post assesment of longer-term program engagement. Technical report, IMF, Staff Team, May 2004.

S. Johansen. Statistical analysis of cointegrating vectors. Journal of Economic Dynamics and Control, 12:231-254, 1988.

S. Johansen, R. Mosconi, and B. Nielsen. Cointegration analysis in the presence of structural breaks in the deterministic trend. Econometrics Journal, 3:216-249, 2000.

P. Jorion and R. Sweeney. Mean reversion in real exchange rates: Evidence and implications for forecasting. Journal of International Money and Finance, 15:550-50, 1996.

S. Karlsson and M. Löthgren. On the power and interpretation of panel unit root tests. Economics Letters, 66:249-255, 2000.

B. Y. Kim and I. Korhonen. Equilibrium exchange rates in transition countries: Evidence from dynamic heterogeneous panel models. Technical report, Discussion Paper No. 15, Bank of Finland Institute for Economies in Transition BOFIT, 2002.

E. Kočenda. Beware of breaks in exchange rates: Evidence from european transition countries. Discussion Paper Series, Center for Economic Policy Research, 2005.

M. Lee. Purchasing Power Parity. New York, 1976.

A. Levin, C. Lin, and C. J. Chu. Unit root tests in panel data: Asymptotic and finite sample properties. Journal of Econometrics, 108:1-24, 2002.

A. Levin and Chien-FU Lin. Unit root tests in panel data: Asymptotic and finite sample results. San Diego: Working Paper, University of California, 1992.

J. Lothian and M. Taylor. Real exchange rate behavior: The recent float from the perspective of the past two centuries. Journal of Political Economy, 104:488-509, 1995.

R. Lumsdaine and D. Papell. Multiple trend breaks and unit-root hypothesis. Review of Economics and Statistics, 79:212-218, 1997.

H. Lütkepohl, P. Saikkonen, and C. Trenkler. Testing for the cointegrating rank of a var process with level shift at unknown time. Econometrica, 72(2):647-662, 2004. 
R. MacDonald. Panel unit root tests and real exchange rates. Economics Letter, 50:7-11, 1996.

R. Messe and K. Rogoff. Was it real? the exchange rate interest differential relation over the modern floating exchange rate period. Journal of International Economics, 43:933-948, 1988.

M. Nelson. Real exchange rates in the long-run: An empirical investigation. Journal of International Economics, 28:115-136, 1990.

S. Ng and P. Perron. Ppp may not hold afterall: A further investigation. Annals of Economics and Finance, 3:43-64, 2002.

M. Obstfeld. Model trending real exchange rates. Working paper C93-011, Center for International and Development Economic Research, 1993.

P. O'Connell. The overvaluation of purchasing power parity. Journal of International Economics, 44:1-9, 1998.

D. Papell. Searching for stationarity: Purchasing power parity under the current float. Journal of International Economics, 43:313-332, 1997.

D. Papell and H. Theodoridis. Increasing evidence of purchasing power parity over the current float. Journal of International Money and Finance, 17:41-50, 1998.

D. H. Papell and R. Prodan. Long run purcahsing power parity: Cassel or balassa-samuelson? University of Houston, November 2003.

P. Perron. The great crash, the oil price stock and the unit root hypothesis. Econometrica, 57: 1361-1401, 1989.

P. Perron and G. Rodríguez. Searching for additive outliers in nonstationary time series. Journal of Time Series Analysis, 24(2):193-220, 2003.

P. C. B. Phillips and H. R. Moon. Linear regression limit theory for nonstationarity panel data. Econometrica, 67:1057-1111, 1999.

P. Saikkonen and H. Lütkepohl. Testing for the cointegrating rank of a var process with structural shifts. Journal of Business and Economic Statistics, 18:451-464, 2000.

P. A. Samuelson. Theoretical notes of trade problems. Review of Economics and Statistics, 46(2): $145-154,1964$.

L. Sarno and P. M. Taylor. The behavior of real exchange rates during the post-breton woods period. Journal of International Economics, 46:281-312, 1998. 
D. W. Shin, R. Sarkar, and J. H. Lee. Unit root tests for time series with outliers. Stat. Prob. Lett., 30:189-97, 1996.

R. Sweeney. Mean reversion in g-10 nominal exchange rates. Journal of Financial and Quantitative Analysis, January 2005. Working Paper, Georgetown University.

T. J. Vogelsang. Two simple procedures for testing for a unit root when there are additive outliers. International Journal of Finance and Economics, 20:237-252, 1999.

Y. Wu. Are real exchange rates nonstationary? evidence from a panel-data test. Journal of Money, Credit, and Banking, 28:54-63, 1996.

E. Zivot and D. W. K. Andrews. Further evidence on the great crash, the oil price stock, and the unit-root hypothesis. Journal of Business and Economic Statistics, 10(3):251-270, 1992. 
Table 1: Exchange-rate regimes.

\begin{tabular}{ll}
\hline \hline Bulgaria & Regime \\
& $\begin{array}{l}\text { Independent float from February 1991, } \\
\text { Currency-board from July } 1997\end{array}$ \\
& Fixed(basked-peg) from January 1991, \\
& Crawling bands from 1996, \\
& Managed float from May 1997 \\
Estonia & Currency-board from June 1992 \\
Hungary & Adjustable peg (basket-peg) to ECU until March 1995, \\
& Pre-announced crawling band (peg) from March 1995 \\
Latvia & Independent float from July 1992 to 1993, \\
& Conventional fixed peg from 1993 (in reality, peg to SDR basket) \\
Lithuania & Independent float from October 1992 to April 1994, \\
& Currency-board from April 1994 \\
Poland & Pre-announced crawling peg from October 1991, \\
& Float within crawling band from May 1995, \\
& Independent float from 2000 \\
Romania & Managed float from August 1992 \\
Slovakia & Crawling bands from 1996 to 1997, \\
& Managed float from October 1998 \\
Slovenia & Managed float with no pre-announced exchange rate path from 1992, \\
\hline NOTE: Source: & Kočenda (2005), Halpern and Wyplosz (2001)
\end{tabular}


Table 2: Basic statistics of logs of real exchange-rates and of the first differences of logs of real exchange-rates

\begin{tabular}{|c|c|c|c|c|c|c|}
\hline & \multicolumn{4}{|c|}{ Logs of real exchange-rate } & \multicolumn{2}{|c|}{$\begin{array}{l}\text { The first difference of } \\
\text { logs of real exchange-rate }\end{array}$} \\
\hline & $\begin{array}{l}\text { U.S. \$ } \\
\text { Mean }\end{array}$ & $\begin{array}{l}\text { U.S. \$ } \\
\text { St.Dev. }\end{array}$ & $\operatorname{Corr}(\mathrm{S}, \mathrm{r})$ & $\operatorname{Corr}(\mathrm{P}, \mathrm{r})$ & $\begin{array}{l}\text { U.S. \$ } \\
\text { Mean }\end{array}$ & $\begin{array}{l}\text { U.S. \$ } \\
\text { St.Dev. }\end{array}$ \\
\hline Bulgaria & -0.754 & 0.192 & -0.545 & -0.668 & -0.006 & 0.099 \\
\hline Czech Republic & 3.536 & 0.115 & 0.519 & -0.390 & -0.004 & 0.036 \\
\hline Estonia & 2.830 & 0.262 & -0.048 & -0.780 & -0.008 & 0.031 \\
\hline Hungary & 5.481 & 0.097 & 0.468 & 0.087 & -0.002 & 0.026 \\
\hline Latvia & -0.403 & 0.247 & 0.514 & -0.870 & -0.009 & 0.025 \\
\hline Lithuania & 1.545 & 0.397 & 0.589 & -0.947 & -0.015 & 0.034 \\
\hline Poland & 1.415 & 0.081 & -0.296 & -0.487 & -0.002 & 0.028 \\
\hline Romania & 9.999 & 0.130 & -0.405 & -0.465 & -0.004 & 0.055 \\
\hline Slovakia & 3.742 & 0.114 & 0.371 & -0.314 & -0.004 & 0.027 \\
\hline Slovenia & 5.251 & 0.124 & 0.756 & -0.424 & -0.001 & 0.030 \\
\hline
\end{tabular}

NOTE: $S$ is the nominal exchange-rate; $P$ is domestic CPI relative to U.S. CPI; and $r$ is log of the real exchange rate. 
Table 3: Univariate Unit-Root Test Results

\begin{tabular}{|c|c|c|c|c|c|c|c|c|c|}
\hline \multicolumn{10}{|c|}{ A. Real Exchange Rates: USD Base, Consumer Price Indices } \\
\hline Country & $A D F$ & $B M 1$ & $B M^{2}$ & BM3 & $\mathrm{BM}_{4}$ & $B M 1-O$ & BM2-O & BM3-O & $\mathrm{BM}_{4}-\mathrm{O}$ \\
\hline Bulgaria & $10 \%$ & $5 \%$ & $5 \%$ & $1 \%$ & $\mathrm{~N}$ & $1 \%$ & $\mathrm{~N}$ & $2.5 \%$ & $1 \%$ \\
\hline Czech Republic & $\mathrm{N}$ & $\mathrm{N}$ & $\mathrm{N}$ & $\mathrm{N}$ & $\mathrm{N}$ & $2.5 \%$ & $1 \%$ & $\mathrm{~N}$ & $1 \%$ \\
\hline Estonia & $2.5 \%$ & $1 \%$ & $1 \%$ & $5 \%$ & $\mathrm{~N}$ & $\mathrm{~N}$ & $\mathrm{~N}$ & $\mathrm{~N}$ & $\mathrm{~N}$ \\
\hline Hungary & $\mathrm{N}$ & $\mathrm{N}$ & $\mathrm{N}$ & $10 \%$ & $10 \%$ & $10 \%$ & $2.5 \%$ & $\mathrm{~N}$ & $1 \%$ \\
\hline Latvia & $1 \%$ & $1 \%$ & $1 \%$ & $1 \%$ & $\mathrm{~N}$ & $\mathrm{~N}$ & $\mathrm{~N}$ & $\mathrm{~N}$ & $\mathrm{~N}$ \\
\hline Lithuania & $1 \%$ & $1 \%$ & $\mathrm{~N}$ & $\mathrm{~N}$ & $\mathrm{~N}$ & $\mathrm{~N}$ & $\mathrm{~N}$ & $\mathrm{~N}$ & $\mathrm{~N}$ \\
\hline Poland & $2.5 \%$ & $2.5 \%$ & $1 \%$ & $\mathrm{~N}$ & $\mathrm{~N}$ & $\mathrm{~N}$ & $\mathrm{~N}$ & $\mathrm{~N}$ & $\mathrm{~N}$ \\
\hline Romania & $2.5 \%$ & $1 \%$ & $\mathrm{~N}$ & $\mathrm{~N}$ & $10 \%$ & $\mathrm{~N}$ & $\mathrm{~N}$ & $\mathrm{~N}$ & $\mathrm{~N}$ \\
\hline Slovakia & $\mathrm{N}$ & $\mathrm{N}$ & $\mathrm{N}$ & $\mathrm{N}$ & $\mathrm{N}$ & $\mathrm{N}$ & $\mathrm{N}$ & $\mathrm{N}$ & $\mathrm{N}$ \\
\hline Slovenia & $\mathrm{N}$ & $2.5 \%$ & $\mathrm{~N}$ & $10 \%$ & $\mathrm{~N}$ & $\mathrm{~N}$ & $\mathrm{~N}$ & $\mathrm{~N}$ & $\mathrm{~N}$ \\
\hline \multicolumn{10}{|c|}{ B. Real Exchange Rates: Euro Base, Consumer Price Indices } \\
\hline Bulgaria & $\mathrm{N}$ & $1 \%$ & $1 \%$ & $\mathrm{~N}$ & $1 \%$ & $1 \%$ & $1 \%$ & $\mathrm{~N}$ & $\mathrm{~N}$ \\
\hline Czech Republic & $\mathrm{N}$ & $\mathrm{N}$ & $5 \%$ & $2.5 \%$ & $1 \%$ & $2.5 \%$ & $\mathrm{~N}$ & $2.5 \%$ & $1 \%$ \\
\hline Estonia & $\mathrm{N}$ & $5 \%$ & $1 \%$ & $\mathrm{~N}$ & $1 \%$ & $\mathrm{~N}$ & $\mathrm{~N}$ & $\mathrm{~N}$ & $\mathrm{~N}$ \\
\hline Hungary & $\mathrm{N}$ & $\mathrm{N}$ & $2.5 \%$ & $\mathrm{~N}$ & $\mathrm{~N}$ & $\mathrm{~N}$ & $1 \%$ & $\mathrm{~N}$ & $\mathrm{~N}$ \\
\hline Latvia & $\mathrm{N}$ & $1 \%$ & $1 \%$ & $\mathrm{~N}$ & $1 \%$ & $\mathrm{~N}$ & $\mathrm{~N}$ & $10 \%$ & $\mathrm{~N}$ \\
\hline Lithuania & $\mathrm{N}$ & $\mathrm{N}$ & $1 \%$ & $\mathrm{~N}$ & $1 \%$ & $\mathrm{~N}$ & $\mathrm{~N}$ & $\mathrm{~N}$ & $\mathrm{~N}$ \\
\hline Poland & $\mathrm{N}$ & $1 \%$ & $\mathrm{~N}$ & $1 \%$ & $10 \%$ & $\mathrm{~N}$ & $\mathrm{~N}$ & $\mathrm{~N}$ & $\mathrm{~N}$ \\
\hline Romania & $\mathrm{N}$ & $1 \%$ & $\mathrm{~N}$ & $\mathrm{~N}$ & $1 \%$ & $1 \%$ & $\mathrm{~N}$ & $5 \%$ & $1 \%$ \\
\hline Slovakia & $\mathrm{N}$ & $\mathrm{N}$ & $1 \%$ & $5 \%$ & $1 \%$ & $\mathrm{~N}$ & $1 \%$ & $5 \%$ & $1 \%$ \\
\hline Slovenia & $\mathrm{N}$ & $1 \%$ & $1 \%$ & $1 \%$ & $1 \%$ & $\mathrm{~N}$ & $\mathrm{~N}$ & $\mathrm{~N}$ & $\mathrm{~N}$ \\
\hline \multicolumn{10}{|c|}{ C. Real Exchange Rates: USD Base, Producer Price Indices } \\
\hline Bulgaria & $10 \%$ & $1 \%$ & $\mathrm{~N}$ & $2.5 \%$ & $\mathrm{~N}$ & $2.5 \%$ & $\mathrm{~N}$ & $1 \%$ & $1 \%$ \\
\hline Czech Republic & $\mathrm{N}$ & $\mathrm{N}$ & $\mathrm{N}$ & $\mathrm{N}$ & $\mathrm{N}$ & $2.5 \%$ & $1 \%$ & $10 \%$ & $\mathrm{~N}$ \\
\hline Estonia & $\mathrm{N}$ & $1 \%$ & $2.5 \%$ & $2.5 \%$ & $\mathrm{~N}$ & $\mathrm{~N}$ & $\mathrm{~N}$ & $\mathrm{~N}$ & $\mathrm{~N}$ \\
\hline Hungary & $\mathrm{N}$ & $\mathrm{N}$ & $\mathrm{N}$ & $\mathrm{N}$ & $2.5 \%$ & $\mathrm{~N}$ & $\mathrm{~N}$ & $\mathrm{~N}$ & $1 \%$ \\
\hline Latvia & $1 \%$ & $5 \%$ & $5 \%$ & $10 \%$ & $\mathrm{~N}$ & $\mathrm{~N}$ & $\mathrm{~N}$ & $\mathrm{~N}$ & $\mathrm{~N}$ \\
\hline Lithuania & $\mathrm{N}$ & $1 \%$ & $5 \%$ & $\mathrm{~N}$ & $\mathrm{~N}$ & $\mathrm{~N}$ & $\mathrm{~N}$ & $\mathrm{~N}$ & $\mathrm{~N}$ \\
\hline Poland & $\mathrm{N}$ & $10 \%$ & $10 \%$ & $\mathrm{~N}$ & $\mathrm{~N}$ & $\mathrm{~N}$ & $\mathrm{~N}$ & $\mathrm{~N}$ & $\mathrm{~N}$ \\
\hline Romania & $\mathrm{N}$ & $1 \%$ & $1 \%$ & $1 \%$ & $\mathrm{~N}$ & $1 \%$ & $\mathrm{~N}$ & $\mathrm{~N}$ & $\mathrm{~N}$ \\
\hline Slovakia & $\mathrm{N}$ & $\mathrm{N}$ & $\mathrm{N}$ & $\mathrm{N}$ & $\mathrm{N}$ & $\mathrm{N}$ & $\mathrm{N}$ & $\mathrm{N}$ & $\mathrm{N}$ \\
\hline Slovenia & $\mathrm{N}$ & $5 \%$ & $\mathrm{~N}$ & $\mathrm{~N}$ & $\mathrm{~N}$ & $\mathrm{~N}$ & $\mathrm{~N}$ & $\mathrm{~N}$ & $\mathrm{~N}$ \\
\hline
\end{tabular}

NOTE: Significance of the slope on lagged log real exchange rate is indicated at the $10 \%, 5 \%, 2.5 \%$ and $1 \%$ levels. $N$ indicates that the slope on the lagged log real exchange rate is not significant at even the $10 \%$ level. The models are as follows. $A D F$ : Augmented Dickey-Fuller. $B M 1$ : Break Model 1. BM2: Break Model 2. BM3: Break Model 3. BM4: Break Model 4. BM1 - O: Break Model 1 with Outliers. BM2-O: Break Model 2 with Outliers. BM3 - O: Break Model 3 with Outliers. BM4-O: Break Model 4 with Outliers. 
Table 4: Tests for unit roots in real exchange rates, using the standard Augmented-Dickey-Fuller equation:

\begin{tabular}{lllll}
\multicolumn{4}{c}{$\Delta r_{t}=\mu+\alpha r_{t-1}+\sum_{i=1}^{k} \gamma_{i} \Delta r_{t-i}+\varepsilon_{t}$} & \\
\hline \hline Bulgaria & $k$ & $\hat{\mu}$ & $\hat{\alpha}$ & $S(\hat{e})$ \\
& $\mathrm{k}=0$ & -0.091 & -0.128 & 0.0093 \\
Estonia & & $(2.606)$ & $(-2.854)^{*}$ & \\
& $\mathrm{k}=7$ & 0.124 & -0.0463 & 0.00130 \\
Latvia & $\mathrm{k}=5$ & -0.033 & -0.061 & 0.0002 \\
& & $(-5.819)$ & $(-5.575)^{* * * *}$ & \\
Lithuania & $\mathrm{k}=3$ & 0.080 & -0.061 & 0.0004 \\
& & $(6.076)$ & $(-6.530)^{* * * *}$ & \\
Poland & $\mathrm{k}=12$ & 0.173 & -0.124 & 0.0007 \\
& & $(2.927)$ & $(-2.974)^{* * *}$ & \\
Romania & $\mathrm{k}=2$ & 1.215 & -0.121 & 0.0027 \\
& & $(3.094)$ & $(-3.107)^{* * *}$ & \\
\hline
\end{tabular}

NOTE: $r$ is the log of the real exchange per CPIs, with the USD as the base currency. t-statistics are in parentheses. The t-statistics for $\hat{\alpha}$ is for testing $\alpha=0$. The symbols $*, * *, * * *$ and $* * * *$ denote significance of the test for $\alpha=0$ at the $10 \%, 5 \%, 2.5 \%$ and $1 \%$ levels, using critical values from simulation. 
Table 5: Tests for unit roots in real exchange rates, using Break Model 1:

\begin{tabular}{|c|c|c|c|c|c|c|}
\hline & $\overline{\overline{T_{\mu}^{1}}}$ & $\bar{k}$ & 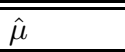 & $\overline{\bar{\theta}}$ & $\overline{\bar{\alpha}}$ & $\overline{S S(\hat{e})}$ \\
\hline Bulgaria & $1997-01$ & $\mathrm{k}=8$ & $\begin{array}{l}-0.238 \\
(3.799)\end{array}$ & $\begin{array}{l}-0.081 \\
(-3.726)\end{array}$ & $\begin{array}{l}-0.250 \\
(-3.614)^{* *}\end{array}$ & 0.0082 \\
\hline Estonia & $2002-03$ & $\mathrm{k}=11$ & $\begin{array}{l}0.245 \\
(4.662)\end{array}$ & $\begin{array}{l}-0.022 \\
(-2.937)\end{array}$ & $\begin{array}{l}-0.089 \\
(-4.691)^{* * * *}\end{array}$ & ${ }_{*}^{0.00078}$ \\
\hline Latvia & 1996-06 & $\mathrm{k}=5$ & $\begin{array}{l}-0.036 \\
(-6.007)\end{array}$ & $\begin{array}{l}-0.007 \\
(1.501)\end{array}$ & $\begin{array}{l}-0.055 \\
(-4.771)^{* * * *}\end{array}$ & $\begin{array}{l}0.00023 \\
*\end{array}$ \\
\hline Lithuania & 2002-03 & $\mathrm{k}=3$ & $\begin{array}{l}0.123 \\
(8.468)\end{array}$ & $\begin{array}{l}-0.028 \\
(-5.209)\end{array}$ & $\begin{array}{l}-0.089 \\
(-8.859)^{* * * *}\end{array}$ & ${ }_{*}^{0.00036}$ \\
\hline Poland & 1994-08 & $\mathrm{k}=1$ & $\begin{array}{l}0.253 \\
(3.617)\end{array}$ & $\begin{array}{l}-0.029 \\
(-2.861)\end{array}$ & $\begin{array}{l}-0.162 \\
(-3.637)^{* * *}\end{array}$ & 0.00071 \\
\hline Romania & 1997-02 & $\mathrm{k}=1$ & $\begin{array}{l}1.999 \\
(4.802)\end{array}$ & $\begin{array}{l}0.035 \\
(-3.310)\end{array}$ & $\begin{array}{l}-0.198 \\
(-4.800)^{* * * *}\end{array}$ & $\begin{array}{l}0.0025 \\
*\end{array}$ \\
\hline Slovenia & 1998-12 & $\mathrm{k}=11$ & $\begin{array}{l}0.694 \\
(3.767)\end{array}$ & $\begin{array}{l}0.024 \\
(3.083)\end{array}$ & $\begin{array}{l}-0.135 \\
(-3.782)^{* * *}\end{array}$ & 0.00079 \\
\hline
\end{tabular}

NOTE: $r$ is the log of the real exchange per CPIs, with the USD as the base currency. $D_{\mu, t}$ is a dummy, equal to zero for $t<\hat{T}_{\mu}^{1}$ and equal to unity for $t \geq \hat{T}_{\mu}^{1}$, where $\hat{T}_{\mu}^{1}$ is the estimated time at which the intercept shifts in Model 1. t-statistics are in parentheses. The t-statistic for $\hat{\alpha}$ is for testing the null $\alpha=0$. The symbols $*, * *, * * *$ and $* * * *$ denote significance of the test of $\alpha=0$ at $10 \%, 5 \%, 2.5 \%$ and $1 \%$ levels, using critical values from simulation. 
Table 6: Unit-root tests for real exchange rates, using Break Model 2: $\Delta r_{t}=\left[\mu+\theta D_{\mu, t}\right]+\beta t+\alpha r_{t-1}+\sum_{i=1}^{k} \gamma_{i} \Delta r_{t-i}+\varepsilon_{t}$

\begin{tabular}{|c|c|c|c|c|c|c|c|}
\hline & $\hat{T}_{\mu}^{2}$ & $k$ & $\hat{\mu}$ & $\widehat{\hat{\theta}}$ & $\widehat{\hat{\beta}}$ & $\hat{\alpha}$ & $\overline{S(\hat{e})}$ \\
\hline Bulgaria & 1999-12 & $\mathrm{k}=8$ & $\begin{array}{l}0.380 \\
(-3.827)\end{array}$ & $\begin{array}{l}-0.002 \\
(-3.194)\end{array}$ & $\begin{array}{l}0.068 \\
(1.927)\end{array}$ & $\begin{array}{l}-0.356 \\
(-3.836)^{* *}\end{array}$ & 0.00844 \\
\hline Estonia & 1999-01 & $\mathrm{k}=12$ & $\begin{array}{l}0.412 \\
(5.754)\end{array}$ & $\begin{array}{l}-0.048 \\
(3.868)\end{array}$ & $\begin{array}{l}0.0008 \\
(-4.159)\end{array}$ & $\begin{array}{l}-0.140 \\
(-5.789)^{* * * *}\end{array}$ & 0.00073 \\
\hline Latvia & $2002-11$ & $\mathrm{k}=7$ & $\begin{array}{l}-0.062 \\
(-7.343)\end{array}$ & $\begin{array}{l}-0.024 \\
(-4.092)\end{array}$ & $\begin{array}{l}0.0003 \\
(2.556)\end{array}$ & $\begin{array}{l}-0.097 \\
(-6.892)^{* * * *}\end{array}$ & 0.00020 \\
\hline Poland & 1998-07 & $\mathrm{k}=13$ & $\begin{array}{l}0.348 \\
(4.370)\end{array}$ & $\begin{array}{l}0.035 \\
(3.082)\end{array}$ & $\begin{array}{l}-0.0005 \\
(-2.936)\end{array}$ & $\begin{array}{l}-0.236 \\
(-4.438)^{* * * *}\end{array}$ & 0.00068 \\
\hline
\end{tabular}

NOTE: $r$ is the log of the real exchange per CPIs, with the USD as the base currency. $D_{\mu, t}$ is a dummy, equal to zero for $t<\hat{T}_{\mu}^{2}$ and equal to unity for $t \geq \hat{T}_{\mu}^{2}$, where $\hat{T}_{\mu}^{2}$ is the estimated time at which the intercept shifts in Model 2. $t$ is the time trend. t-statistics are in parentheses. The t-statistic for $\hat{\alpha}$ is for testing the null $\alpha=0$. The symbols $*, * *, * * *$, and $* * * *$ denote significance of the test for $\alpha=0$ at the $10 \%, 5 \%, 2.5 \%$ and $1 \%$ levels, using the critical values from Table 2 of Zivot and Andrews (1992).

Table 7: Unit-root tests for real exchange rates, using Break Model 3:

\begin{tabular}{|c|c|c|c|c|c|c|c|}
\hline & $\hat{T}_{\beta}^{3}$ & $k$ & $\hat{\mu}$ & $\widehat{\hat{\beta}}$ & $\hat{\phi}$ & $\hat{\alpha}$ & $\overline{S(\hat{e})}$ \\
\hline Bulgaria & $2002-09$ & $\mathrm{k}=0$ & $\begin{array}{l}0.238 \\
(-4.042)\end{array}$ & $\begin{array}{l}-0.0007 \\
(-2.221)\end{array}$ & $\begin{array}{l}-0.006 \\
(-1.692)\end{array}$ & $\begin{array}{l}-0.257 \\
(-4.347)^{* * * *}\end{array}$ & 0.00872 \\
\hline Estonia & 1994-01 & $\mathrm{k}=11$ & $\begin{array}{l}0.211 \\
(3.811)\end{array}$ & $\begin{array}{l}-0.0002 \\
(3.383)\end{array}$ & $\begin{array}{l}-0.0003 \\
(-3.084)\end{array}$ & $\begin{array}{l}-0.062 \\
(-3.920)^{* *}\end{array}$ & 0.00084 \\
\hline Hungary & 2001-11 & $\mathrm{k}=11$ & $\begin{array}{l}1.338 \\
(3.563)\end{array}$ & $\begin{array}{l}0.0005 \\
(2.947)\end{array}$ & $\begin{array}{l}-0.004 \\
(-3.594)\end{array}$ & $\begin{array}{l}-0.249 \\
(-3.560)^{*}\end{array}$ & 0.00063 \\
\hline Latvia & 2002-09 & $\mathrm{k}=7$ & $\begin{array}{l}-0.060 \\
(-6.962)\end{array}$ & $\begin{array}{l}0.0001 \\
(2.113)\end{array}$ & $\begin{array}{l}-0.003 \\
(-3.824)\end{array}$ & $\begin{array}{l}-0.096 \\
(-6.766)^{* * * *}\end{array}$ & 0.00020 \\
\hline Slovenia & 2002-03 & $\mathrm{k}=9$ & $\begin{array}{l}0.570 \\
(3.519)\end{array}$ & $\begin{array}{l}0.0004 \\
(3.112)\end{array}$ & $\begin{array}{l}-0.002 \\
(-3.070)\end{array}$ & $\begin{array}{l}-0.114 \\
(-3.550)^{*}\end{array}$ & 0.00077 \\
\hline
\end{tabular}

NOTE: $r$ is the log of the real exchange per CPIs, with the USD as the base currency. $t$ is the time trend. $D_{\beta, t}$ is a dummy, equal to zero for $t<\hat{T}_{\beta}^{3}$ and equal to unity for $t \geq \hat{T}_{\beta}^{3}$, where $\hat{T}_{\beta}^{3}$ is the estimated time at which the trend coefficient shifts in Model 3. t-statistics are in parentheses. $k$ is determined as described in Section 2. The t-statistic for $\hat{\alpha}$ is for testing $\alpha=0$. The symbols $*, * *, * * *$, and $* * * *$ denote significance of the test for $\alpha=0$ at the $10 \%, 5 \%, 2.5 \%$ and $1 \%$ levels, using the critical values from Table 3 of Zivot and Andrews (1992). 
Table 8: Unit-root tests for real exchange rates, using Break Model 4: $\Delta r_{t}=\left[\mu+\theta D_{\mu, t}\right]+\left[\beta t+\phi D_{\beta, t}\left(t-T_{b}\right)\right]+\alpha r_{t-1}+\sum_{i=1}^{k} \gamma_{i} \Delta r_{t-i}+\varepsilon_{t}$

\begin{tabular}{lllllllll}
\hline \hline Country & $\hat{T}_{b}^{4}$ & $k$ & $\hat{\mu}$ & $\hat{\beta}$ & $\hat{\theta}$ & $\hat{\phi}$ & $\hat{\alpha}$ & $S(\hat{e})$ \\
\hline Hungary & $2000-02$ & $\mathrm{k}=0$ & 1.110 & 0.0003 & 0.045 & -0.003 & -0.205 & 0.00058 \\
& & & $(4.123)$ & $(2.334)$ & $(3.227)$ & $(-4.642)$ & $(-4.124)^{*}$ & \\
\multirow{2}{*}{ Romania } & \multirow{2}{*}{$1997-02$} & $\mathrm{k}=2$ & 1.713 & -0.002 & -0.081 & -0.002 & -0.175 & 0.00234 \\
& & & $(3.941)$ & $(3.457)$ & $(-4.420)$ & $(-2.970)$ & $(-4.070)^{*}$ & \\
\hline
\end{tabular}

NOTE: $r$ is the log of the real exchange per CPIs, with the USD as the base currency. $D_{\mu, t}$ is a dummy, equal to zero for $t<\hat{T}_{b}^{4}$ and equal to unity for $t \geq \hat{T}_{b}^{4}$. $D_{\beta, t}$ is a dummy, equal to zero for $t<\hat{T}_{b}^{4}$ and equal to unity for $t \geq \hat{T}_{b}^{4} \cdot \hat{T}_{b}^{4}$ is the estimated time at which both the intercept and the trend coefficients shift in Model 4 . t-statistics are in parentheses. The t-statistic for $\hat{\alpha}$ is for testing the null $\alpha=0$. The symbols $*, * *, * * *$ and $* * * *$ denote significance of the test for $\alpha=0$ at the $10 \%, 5 \%, 2.5 \%$ and $1 \%$ levels, using the critical values from Table 4 of Zivot and Andrews (1992).

Table 9: Unit-root tests for real exchange rates, using Break Model 1 with outliers:

\begin{tabular}{|c|c|c|c|c|c|c|c|c|}
\hline & $\overline{\hat{T}_{\mu}^{1}}$ & $\overline{\hat{T}_{a o}}$ & $\overline{p p}$ & 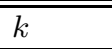 & $\overline{\bar{\mu}}$ & $\overline{\bar{\theta}}$ & $\overline{\bar{\alpha}}$ & 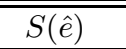 \\
\hline Bulgaria & $1997-01$ & 1997-01 & $p=2$ & $k=1$ & $\begin{array}{l}-0.519 \\
(3.702)\end{array}$ & $\begin{array}{l}-0.057 \\
(-2.973)\end{array}$ & $\begin{array}{l}-0.207 \\
(-3.746)^{* * * *}\end{array}$ & 0.0063 \\
\hline Czech Republic & $2002-02$ & 2003-05 & $p=1$ & $k=0$ & $\begin{array}{l}0.334 \\
(3.125)\end{array}$ & $\begin{array}{l}-0.024 \\
(-2.529)\end{array}$ & $\begin{array}{l}-0.100 \\
(-3.139)^{* * *}\end{array}$ & 0.0011 \\
\hline Hungary & 1994-07 & 2003-05 & $p=1$ & $k=12$ & $\begin{array}{l}0.424 \\
(2.231)\end{array}$ & $\begin{array}{l}0.267 \\
(2.201)\end{array}$ & $\begin{array}{l}-0.082 \\
(-2.342)^{*}\end{array}$ & 0.00066 \\
\hline Romania & $1997-02$ & 1997-02 & $p=2$ & $k=1$ & $\begin{array}{l}1.071 \\
(2.712)\end{array}$ & $\begin{array}{l}-0.017 \\
(-1.849)\end{array}$ & $\begin{array}{l}-0.106 \\
(-2.713)^{* *}\end{array}$ & 0.00036 \\
\hline
\end{tabular}

NOTE: $r$ is the log of the real exchange per CPIs, with the USD as the base currency. $D_{\mu, t}$ is a dummy, equal to zero for $t<\hat{T}_{\mu}^{1}$ and equal to unity for $t \geq \hat{T}_{\mu}^{1}$, where $\hat{T}_{\mu}^{1}$ is the estimated time at which the intercept shifts in Model 1 . $D_{a o, t-i}$ is a dummy, equal to zero for $t><\hat{T}_{a o}+i$, and equal to unity for $t=\hat{T}_{a o}+i$; the outlier occurs at time $\hat{T}_{a o}$, and $p$ is the number of dummy variables. t-statistics are in parentheses. The t-statistic for $\hat{\alpha}$ is for testing $\alpha=0$. The symbols $*, * *, * * *$ and $* * * *$ denote significance of the test for $\alpha=0$ at the $10 \%, 5 \%, 2.5 \%$ and $1 \%$ levels, using critical values from simulation. 
Table 10: Unit-root tests for real exchange rates, using Break Model 2 with outliers:

\begin{tabular}{llllllllll}
\multicolumn{7}{c}{$\Delta r_{t}=\left[\mu+\theta D_{\mu, t}\right]+\beta t+\sum_{i=0}^{p} \delta_{i} D_{a o, t-i}+\alpha r_{t-1}+\sum_{i=1}^{k} \gamma_{i} \Delta r_{t-i}+\varepsilon_{t}$} \\
\hline \hline & $\hat{T}_{\mu}^{2}$ & $\hat{T}_{a o}$ & $p$ & $k$ & $\hat{\mu}$ & $\hat{\theta}$ & $\hat{\beta}$ & $\hat{\alpha}$ & $S(\hat{e})$ \\
\hline Czech Republic & $1998-10$ & $2003-05$ & $\mathrm{p}=1$ & $\mathrm{k}=9$ & 0.542 & 0.046 & -0.0007 & -0.147 & 0.0011 \\
& & & & & $(3.744)$ & $(3.384)$ & $(-3.301)$ & $(-3.711)^{* * * *}$ \\
Hungary & $2002-03$ & $2003-05$ & $\mathrm{k}=1$ & $\mathrm{k}=7$ & 0.657 & -0.049 & 0.0003 & -0.122 & 0.0006 \\
& & & & & $(2.957)$ & $(-3.723)$ & $(2.230)$ & $(-2.961)^{* * *}$ & $(20)$ \\
\hline
\end{tabular}

NOTE: $r$ is the log of the real exchange per CPIs, with the USD as the base currency. $D_{\mu, t}$ is a dummy, equal to zero for $t<\hat{T}_{\mu}^{2}$ and equal to unity for $t \geq \hat{T}_{\mu}^{2}$, where $\hat{T}_{\mu}^{2}$ is the estimated time at which the intercept shifts in Model 2. $t$ is the time trend. $D_{a o, t-i}$ is a dummy, equal to zero for $t><\hat{T}_{a o}+i$, and equal to unity for $t=\hat{T}_{a o}+i$; the outlier occurs at time $\hat{T}_{a o}$, and $p$ is the number of dummy variables. t-statistics are in parentheses. The t-statistic for $\hat{\alpha}$ is for testing $\alpha=0$. The symbols $*, * *, * * *$ and $* * * *$ denote significance of the test for $\alpha=0$ at the $10 \%, 5 \%$, $2.5 \%$ and $1 \%$ levels, using critical values from simulation.

Table 11: Unit-root tests for real exchange rates, using Break Model 3 with outliers: $\Delta r_{t}=\mu+\left[\beta t+\phi D_{\beta, t}\right]+\sum_{i=0}^{p} \delta_{i} D_{a o, t-i}+\alpha r_{t-1}+\sum_{i=1}^{k} \gamma_{i} \Delta r_{t-i}+\varepsilon_{t}$

\begin{tabular}{llllllllll}
\hline & \multicolumn{1}{l}{$\hat{T}_{\beta}^{3}$} & $\hat{T}_{a o}$ & $p$ & $k$ & $\hat{\mu}$ & $\hat{\beta}$ & $\hat{\phi}$ & $\hat{\alpha}$ & $S(\hat{e})$ \\
\hline Bulgaria & $2002-09$ & $1997-01$ & $\mathrm{p}=2$ & $\mathrm{k}=1$ & 0.227 & -0.0006 & -0.005 & -0.246 & 0.00619 \\
& & & & & $(3.865)$ & $(-2.322)$ & $(-1.880)$ & $(-4.055)^{* * *}$ & \\
\hline
\end{tabular}

NOTE: $r$ is the log of the real exchange per CPIs, with the USD as the base currency. $t$ is the time trend. $D_{\beta, t}$ is a dummy, equal to zero for $t<\hat{T}_{\beta}^{3}$ and equal to unity for $t \geq \hat{T}_{\beta}^{3}$, where $\hat{T}_{\beta}^{3}$ is the estimated time at which the trend coefficient shifts in Model 3. $D_{a o, t-i}$ is a dummy, equal to zero for $t><\hat{T}_{a o}+i$, and equal to unity for $t=\hat{T}_{a o}+i$; the outlier occurs at time $\hat{T}_{a o}$, and $p$ is the number of dummy variables. t-statistics are in parentheses. The t-statistic for $\hat{\alpha}$ is for testing $\alpha=0$. The symbols $*, * *, * * *$ and $* * * *$ denote significance of the test for $\alpha=0$ at the $10 \%, 5 \%, 2.5 \%$ and $1 \%$ levels, using the critical values from simulation. 
Table 12: Unit-root tests for real exchange rates, using Break Model 4 with outliers:

$\Delta r_{t}=\left[\mu+\theta D_{\mu, t}\right]+\left[\beta t+\phi D_{\beta, t}\right]+\sum_{i=0}^{p} \delta_{i} D_{a o, t-i}+\alpha r_{t-1}+\sum_{i=1}^{k} \gamma_{i} \Delta r_{t-i}+\varepsilon_{t}$

\begin{tabular}{|c|c|c|c|c|c|c|c|c|c|c|}
\hline & $\hat{T}_{\beta}^{3}$ & $\hat{T}_{a o}$ & $p$ & $k$ & $\hat{\mu}$ & $\hat{\theta}$ & $\hat{\beta}$ & $\hat{\phi}$ & $\hat{\alpha}$ & $S(\hat{e})$ \\
\hline Bulgaria & $2000-02$ & 1997-01 & $\mathrm{p}=2$ & $\mathrm{k}=1$ & $\begin{array}{l}0.270 \\
(3.983)\end{array}$ & $\begin{array}{l}0.069 \\
(2.118)\end{array}$ & $\begin{array}{l}-0.001 \\
(-2.392)\end{array}$ & $\begin{array}{l}-0.002 \\
(-1.954)\end{array}$ & $\begin{array}{l}-0.279 \\
(-4.256)^{* * * *}\end{array}$ & $\begin{array}{l}0.00614 \\
*\end{array}$ \\
\hline Czech Republic & 1998-12 & 2003-05 & $\mathrm{p}=1$ & $\mathrm{k}=0$ & $\begin{array}{l}0.488 \\
(3.945)\end{array}$ & $\begin{array}{l}0.050 \\
(3.648)\end{array}$ & $\begin{array}{c}-0.0004 \\
(-1.962)\end{array}$ & $\begin{array}{l}-0.0007 \\
(-2.280)\end{array}$ & $\begin{array}{l}-0.134 \\
(-3.996)^{* * * *}\end{array}$ & $\underset{*}{0.0010}$ \\
\hline Hungary & 2000-02 & 2003-05 & $\mathrm{p}=1$ & $\mathrm{k}=0$ & $\begin{array}{l}1.176 \\
(4.378)\end{array}$ & $\begin{array}{l}0.046 \\
(3.364)\end{array}$ & $\begin{array}{l}0.0003 \\
(2.470)\end{array}$ & $\begin{array}{l}-0.003 \\
(-4.760)\end{array}$ & $\begin{array}{l}-0.217 \\
(-4.379)^{* * * *}\end{array}$ & $\begin{array}{l}0.0006 \\
*\end{array}$ \\
\hline
\end{tabular}

NOTE: $r$ is the log of the real exchange per CPIs, with the USD as the base currency. $D_{\mu, t}$ is a dummy, equal to zero for $t<\hat{T}_{b}^{4}$ and equal to unity for $t \geq \hat{T}_{b}^{4} . t$ is the time trend. $D_{\beta, t}$ is a dummy, equal to zero for $t<\hat{T}_{b}^{4}$ and equal to unity for $t \geq \hat{T}_{b}^{4}$. where $\hat{T}_{b}^{4}$ is the estimated time at which both the intercept and the trend coefficients shift in Model 4 . $D_{a o, t-i}$ is a dummy, equal to zero for $t><\hat{T}_{a o}+i$, and equal to unity for $t=\hat{T}_{a o}+i$; the outlier occurs at time $\hat{T}_{a o}$, and $p$ is the number of dummy variables. t-statistics are in parentheses. The t-statistic for $\hat{\alpha}$ is for testing $\alpha=0$. The symbols $*$, **, $* * *$ and $* * * *$ denote significance of the test for $\alpha=0$ at the $10 \%, 5 \%, 2.5 \%$ and $1 \%$ levels, using the critical values from simulation.

Table 13: Panel Unit-Root Test Results: CPIs, USD as base currency

\begin{tabular}{|c|c|c|c|c|c|c|}
\hline \multicolumn{7}{|c|}{ Number of Lags } \\
\hline Model & & 0 & 3 & 6 & 9 & $\overline{\text { individual }}$ \\
\hline \multirow[t]{2}{*}{$\mathrm{ADF}$} & t-value & -18.214 & -11.938 & -9.723 & -9.205 & -10.850 \\
\hline & half life & 12.870 & 14.869 & 14.532 & 13.788 & 13.313 \\
\hline \multirow[t]{2}{*}{ BM1 } & t-value & -15.910 & -12.403 & -10.577 & -10.331 & -12.578 \\
\hline & half life & 11.102 & 10.941 & 10.233 & 8.782 & 8.898 \\
\hline \multirow[t]{2}{*}{ BM2 } & t-value & -12.926 & -9.385 & -9.987 & -9.228 & -11.574 \\
\hline & half life & 9.686 & 7.383 & 8.830 & 7.622 & 7.479 \\
\hline \multirow[t]{2}{*}{ BM3 } & t-value & -13.019 & -10.563 & -10.240 & -9.146 & -11.016 \\
\hline & half life & 9.322 & 9.729 & 8.388 & 7.461 & 7.681 \\
\hline \multirow[t]{2}{*}{ BM4 } & t-value & -12.073 & -10.776 & -9.539 & -9.182 & -10.827 \\
\hline & half life & 8.687 & 8.551 & 8.064 & 6.895 & 6.627 \\
\hline
\end{tabular}

NOTE: The models are as follows. $A D F$ : Augmented Dickey-Fuller. BM1: Break Model 1.

$B M 2$ : Break Model 2. BM3: Break Model 3. BM4: Break Model 4. 
Table 14: Half Lives for transition countries; estimates from univariate models: CPIs, USD as base currency

\begin{tabular}{llllllllll}
\hline \hline & \multicolumn{10}{c}{ Model } \\
\hline Country & $A D F$ & $B M 1$ & BM2 & BM3 & BM4 & BM1-O & BM2-O & $B M 3-O$ & $B M 4-O$ \\
\hline Bulgaria & 5.048 & 2.411 & 1.576 & 2.336 & 2.169 & 2.994 & - & 2.457 & 2.122 \\
Czech Republic & - & - & - & - & - & 6.608 & 4.366 & - & 4.809 \\
Estonia & 14.593 & 7.429 & 4.607 & 10.879 & - & - & - & - & - \\
Hungary & - & - & - & 2.420 & 3.025 & 8.098 & 5.326 & - & 2.836 \\
Latvia & 11.089 & 12.303 & 6.800 & 6.876 & - & - & - & - & - \\
Lithuania & 10.973 & 7.423 & - & - & - & - & - & - & - \\
Poland & 5.210 & 3.912 & 2.574 & - & - & - & - & - & - \\
Romania & 5.328 & 3.140 & - & - & 3.604 & 6.170 & - & - & - \\
Slovakia & - & - & - & - & - & - & - & - & - \\
Slovenia & - & 4.796 & - & 5.748 & - & - & - & - & - \\
\hline
\end{tabular}

NOTE: The models are as follows. ADF: Augmented Dickey-Fuller. BM1: Break Model 1. BM2: Break Model 2. $B M 3$ : Break Model 3. BM4: Break Model 4. BM1-O: Break Model 1 with Outliers. BM2 -O: Break Model 2 with Outliers. $B M 3-O$ : Break Model 3 with Outliers. BM4-O: Break Model 4 with Outliers. 

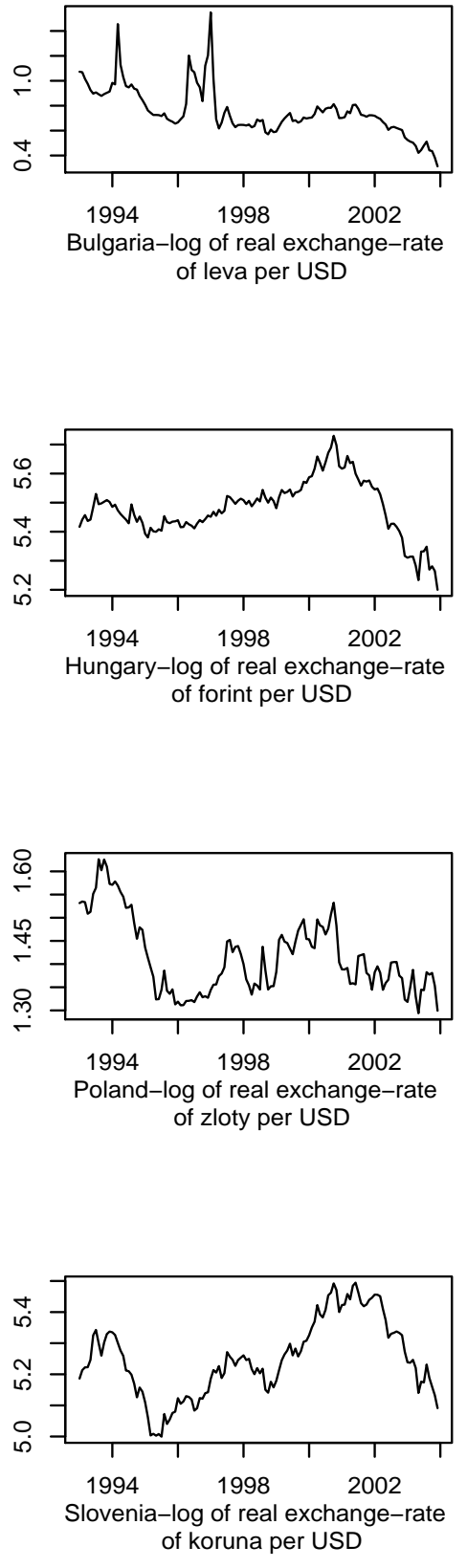
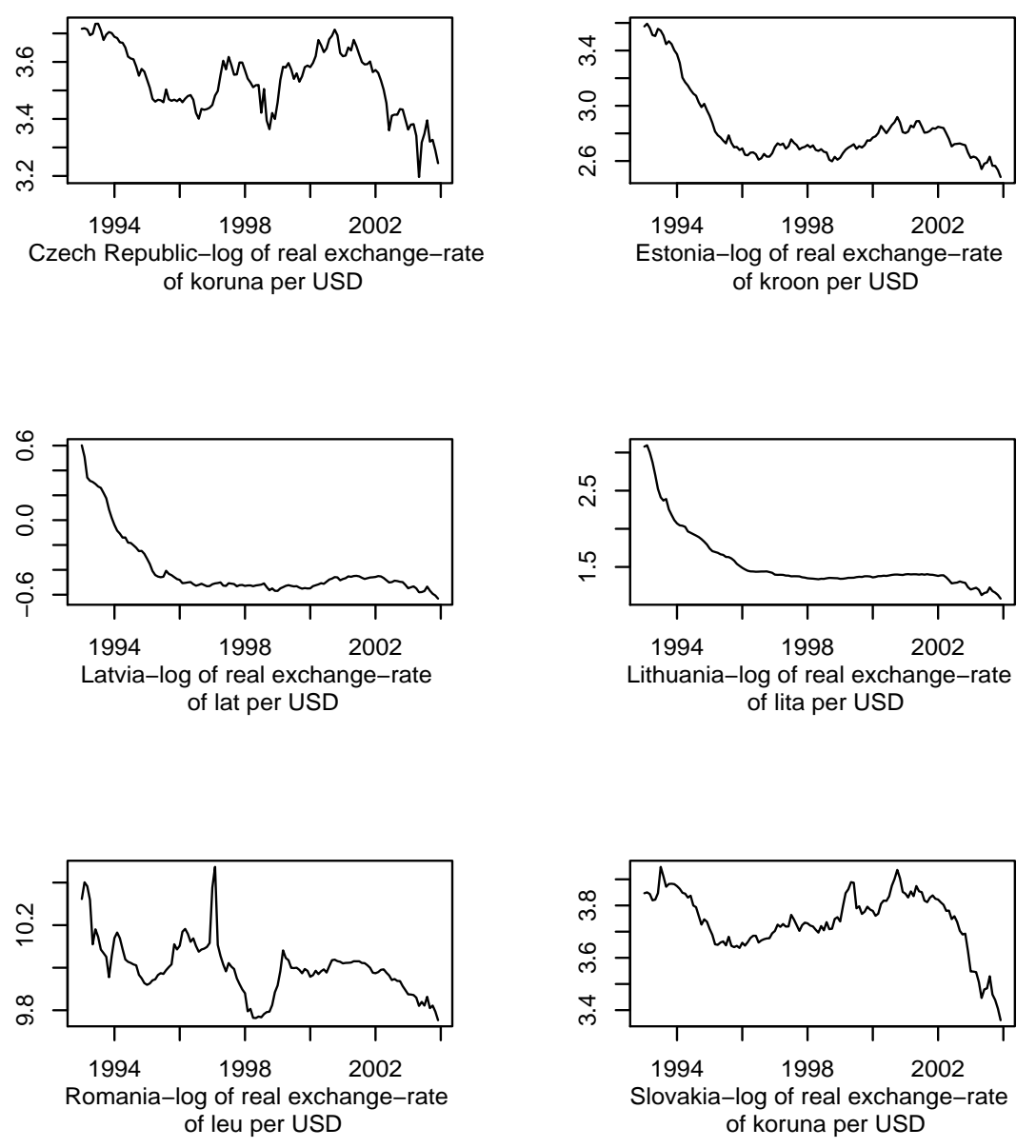

Figure 1: Logarithm of real exchange-rates per USD in ten transition economies 